\title{
O dizível e o indizível: narrativas de dor e violência em cárceres brasileiros
}

In between: painful and violent narratives on the Brazilian prisons

\section{Adriana Rezende Faria Taets}

\section{(2) OpenEdition}

12 Journals

Edição electrónica

URL: http://journals.openedition.org/aa/690

DOI: $10.4000 /$ aa. 690

ISSN: 2357-738X

Editora

Programa de Pós-Graduação em Antropologia Social (UnB)

\section{Edição impressa}

Data de publição: 1 junho 2014

Paginação: 169-194

ISSN: 0102-4302

\section{Refêrencia eletrónica}

Adriana Rezende Faria Taets, «O dizível e o indizível: narrativas de dor e violência em cárceres brasileiros», Anuário Antropológico [Online], v.39 n.1 | 2014, posto online no dia 01 outubro 2014, consultado o 28 abril 2021. URL: http://journals.openedition.org/aa/690 ; DOI: https://doi.org/ 10.4000/aa.690

Este documento foi criado de forma automática no dia 28 abril 2021.

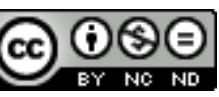

Anuário Antropológico is licensed under a Creative Commons Atribuição-Uso Não-Comercial-Proibição de realização de Obras Derivadas 4.0 International. 


\title{
O dizível e o indizível: narrativas de dor e violência em cárceres brasileiros
}

\author{
In between: painful and violent narratives on the Brazilian prisons
}

Adriana Rezende Faria Taets

\section{NOTA DO EDITOR}

Recebido em: 03/02/2014

Aceito em: 22/04/2014

1 Os cárceres brasileiros são perpassados por relações violentas. A violência, compreendida como uma relação em que há um excesso de poder ou força num dos polos da relação, e um dano, no outro (Chauí, 1985; Gregori, 1993; Tavares, 2009), se dá a partir de diversos pontos no cárcere (Foucault, 1987), estabelecendo ligações diferenciadas, seja entre os próprios detentos e detentas, entre a instituição e os presos, ou ainda entre os(as) guardas e os(as) reclusos(as). O antropólogo, ao se aproximar desta instituição com o intuito de observá-la, depara-se de imediato com histórias e narrativas em que a violência, em suas diversas possibilidades de manifestação e compreensão, se mostra presente.

2 Este artigo foi elaborado a partir dos resultados de minha pesquisa de mestrado (Taets, 2012), que teve como foco as trajetórias de agentes de segurança penitenciária femininas no estado de São Paulo. Tal pesquisa voltou-se principalmente para as narrativas sobre o cárcere a partir do ponto de vista destas agentes, nas quais a dor e a violência se mostraram bastante presentes. Nesta pesquisa, privilegiei a fala de diversas agentes penitenciárias no intuito de compreender suas trajetórias profissionais, o que foi realizado a partir de entrevistas em profundidade com cerca de 10 delas que trabalham na capital e no interior do estado de São Paulo. Para o desenvolvimento deste texto, deter-me-ei na narrativa de uma agente em especial, já que sua fala me 
permite trabalhar questões específicas que envolvem a dor e a memória nas histórias elaboradas sobre o cárcere brasileiro.

Quando iniciei a pesquisa com as agentes prisionais, meu foco voltou-se especificamente para as trajetórias profissionais destas mulheres: interessava-me conhecer as estratégias utilizadas por elas para lidar com o trânsito cotidiano entre o dentro e o fora dos presídios. No entanto, ao me aproximar de algumas dessas mulheres, ao conversar com elas sobre sua profissão, percebi que, mais que construir trajetórias, nossos encontros possibilitavam a elaboração de narrativas sobre algo mais que o exercício profissional. As histórias contadas por tais mulheres extrapolavam o trabalho no interior do cárcere, revelando o quanto as fronteiras entre prisão e sociedade extramuros são porosas. ${ }^{1}$ Pude perceber que há um fluxo contínuo de pessoas, materiais, ideias, sentimentos e convicções entre o interior do presídio e aquilo que se encontra ao seu redor, as narrativas refletindo essa porosidade, derrubando uma ideia de separação rígida entre o dentro e o fora do cárcere.

4 Foi Leonor, uma dessas agentes prisionais, a partir da narrativa sobre sua profissão enquanto guarda, que me possibilitou compreender que o trânsito contínuo entre cárcere e sociedade extramuros é carregado não apenas de ambiguidades - nem sempre é possível saber o que está dentro e o que está fora do cárcere, o que vem de dentro e o que vem de fora - mas é também um movimento bastante delicado e envolto em diversas esferas de dor. Conviver com a precariedade existente nos presídios brasileiros e se sensibilizar com a experiência das pessoas que se encontram reclusas são percebidos como uma experiência dolorosa. Estar dentro do cárcere e não se comover com essa realidade, por sua vez, não se apresenta como uma saída, já que o resultado, de acordo com ela, seria o embrutecimento e o adoecimento do profissional, em especial daqueles que evitam uma postura mais sensível.

5 É possível analisar as narrativas de Leonor a partir daquilo que Veena Das (1999) chamou de trabalho do tempo, em que as experiências dolorosas vão ser organizadas narrativamente e podem, portanto, ser compartilhadas, tornando a experiência violenta algo mais compreensível, porque passível de compartilhamento (Halbwachs, 2006). Violência e dor revelam-se, na narrativa de Leonor, elementos fundamentais para a compreensão de sua própria experiência, no entanto, é o exercício narrativo transformar o vivido em história contada - que permite tal compreensão, e este exercício só é possível através de um distanciamento temporal, como veremos mais à frente.

6 São as narrativas de Leonor, portanto, que norteiam a discussão que proponho neste artigo, e elas se tornam o ponto de partida para questionar a maneira como as narrativas provenientes do cárcere são elaboradas desde elementos que lidam com a dor e a memória, sendo o próprio exercício narrativo - de elaboração e compartilhamento - uma maneira de sobreviver a um cotidiano marcado pela precariedade, pela opressão e pelo medo, transformando tal realidade em algo mais que apenas medo e dor. São as narrativas de Léo que passo, então, a trabalhar aqui.

\section{Advertência}

7 Enquanto me contava aquela história horrível, a Léo me olhava nos olhos. A cada novo elemento na cena, ela se voltava para mim para se certificar de minha atenção. Eu me sentia diluindo por dentro com o horror presente em cada detalhe. Uma mulher, um 
avião, um bebê. Aeromoças, serviço de bordo, passageiros. Tranquilidade, silêncio, ausência de choro. Ausência completa de qualquer choro. Voo internacional, alfândega. Desconfiança. Em solo, uma mulher paraguaia sendo presa em terras brasileiras. Um bebê oco, recheado de pequenos pacotinhos. Tráfico internacional de drogas. Homicídio também? Não sei. Infanticídio? Talvez.

8 A Léo ainda a me olhar nos olhos. Eu seria capaz de suportar aquela história? Voltaria a conversar com ela, a perguntar-lhe sobre acontecimentos, trechos marcantes, relatos de um pedaço de sua vida? Era esta, então, a sua vida? Desviei o olhar. Aquela cena abjeta se desenhando na minha cabeça. Um bebê recheado de drogas. Não podia ser verdade. Não podia. Algo não combinava, faltavam elementos. Não podia ser verdade. Não podia. Olhei novamente para a Léo e, enquanto esperava encontrar em seus olhos uma leve expressão de vitória - sabia que essa garota não suportaria - não pude perceber nela um único traço de maldade.

9 Seus olhos brilhavam com uma doçura triste. Foi ao longo de muitos encontros e muitas conversas que entendi o significado da primeira história que ouvi de Léo. Sua dura narrativa era um convite - um convite triste. Se o que eu buscava era conhecer a sua história - os acontecimentos que marcaram sua memória - eu deveria estar disposta a ter um encontro com a dor. Se eu pudesse enfrentar a dor do horror, da irracionalidade de que é capaz o ser humano, então eu seria bem vinda, e ela me contaria tudo o que eu quisesse saber.

10 Se não fosse capaz de tanto, a história da Léo que eu viria a conhecer seria diferente, ou nossos encontros terminariam ali. $\mathrm{O}$ que eu não imaginava era que a minha persistência acadêmica, que me fez continuar com aqueles encontros - apesar da dor, apesar do horror - me conduziria por caminhos insuspeitados de doçura e cuidado, de reinvenção do ser humano em face de uma opressão extrema e de amor ao próximo.

\section{Encontrando-me com Léo}

11 Leonor é uma guarda conhecida nas rodas dos militantes de direitos humanos que trabalham no cárcere. Lembro-me de ter ouvido histórias sobre ela antes mesmo de dar início à pesquisa de mestrado. 0 que me interessava eram suas histórias de resistência diante do sistema prisional e as diversas transferências entre presídios pelas quais havia passado no decorrer de sua carreira.

12 Como descrevi brevemente acima, logo no nosso primeiro encontro, assim que lhe pedi que me falasse um pouco sobre sua trajetória profissional, as histórias que ouvi vieram carregadas de elementos de violência e dor. Léo, como ela preferia ser chamada, não me poupava dos detalhes cruéis e me escancarava, ali numa padaria qualquer no centro de São Paulo, histórias de loucura e de dor que eu não conseguiria imaginar sozinha. E não foram poucas histórias. A princípio, sentia que ela me testava. Saí daquela primeira conversa abalada. Foram necessárias semanas para que eu conseguisse ligar para ela novamente e agendar um novo encontro.

13 Durante algum tempo achei mesmo que Léo me desafiava propositalmente e aceitei a empreitada. Voltei a conversar com ela. Foi no decorrer de outros encontros, no entanto, que percebi que aquilo não se tratava de um desafio e sim de um convite. As histórias que Léo me contava para traçar sua trajetória eram repletas de dor. Era a dor o marco principal de sua memória (Halbwachs, 2006) e, se eu quisesse conhecer os 
marcos de sua experiência, deveria então ser capaz de compartilhar com ela esses momentos de dor extrema - dela e daquelas que por tanto tempo conviveram com ela em lados diferentes das grades.

\section{Nos meandros da memória e da dor}

14 No segundo encontro que tivemos, Léo chegou munida de diversos recortes de jornais. Quando, na primeira conversa, eu disse que gostaria de conhecer a sua história enquanto guarda, ela me advertiu que tinha uma péssima memória, não se lembrando de muitas coisas, já que acreditava que o uso contínuo de maconha tinha prejudicado seriamente sua capacidade de lembrar. Por ter consciência dessas lacunas de sua memória, Léo coleciona recortes de jornais num esforço de registrar sua própria história e poder voltar a ela depois. Começou, então, a me mostrar fotos, recortes de jornais, cartas de presas que ficaram por algum motivo em seu poder:

Essa foto é um teatro que a gente fez com as bandidas, eu trouxe para você ver como era diferente antes, antes do partido (referindo-se ao Primeiro Comando da Capital - PCC), como as relações ainda eram próximas. Essa daqui é a Maria Emília, a chilena do sequestro do Abílio Diniz.

Metade da foto é escura, sendo possível distinguir apenas algumas silhuetas. Na parte clara da fotografia veem-se três mulheres fazendo alguma brincadeira entre si, têm os rostos pintados, uma delas imitando um gato. É possível perceber os uniformes das presas, típico do sistema prisional paulista: calça cáqui e camiseta branca, todas iguais. Elas sorriem, parecem estar se divertindo.

Depois de me mostrar a fotografia, Léo me entrega alguns recortes de jornais. Todas as notícias relacionam-se com algum tipo de denúncia feita contra o sistema prisional ou o sistema judiciário. "Juiz diz que cumpriu a lei ao manter prisão" é o título de uma reportagem que trata de uma senhora agricultora, de 79 anos, que foi mantida presa por tráfico de drogas (Folha de São Paulo, 28/11/2005, Cotidiano). “'Brasil tem várias Iolandas', afirma Pastoral", reportagem do mesmo jornal no dia seguinte, com o subtítulo "Mulheres detidas por tráfico que têm doença terminal não são raridade em prisões, segundo coordenadora nacional" (Folha de São Paulo, 29/11/2005, Cotidiano). "Ameaçadas, presas são transferidas", reportagem que denuncia maus-tratos e tortura sofridos por presas estrangeiras em confrontos com presas brasileiras ligadas ao PCC (Estado de São Paulo, 14/10/2008, Cidades/Metrópole). Depois dessas reportagens, ela me mostra uma série de outras que tratam dos atentados que ocorreram em maio de 2006 na cidade de São Paulo, e que foram atribuídos ao PCC.

Por fim, Léo me entrega um volume de cartas, todas em inglês, dizendo que foram barradas por um certo diretor que buscava, assim, prejudicar algumas presas estrangeiras que realizavam trabalhos religiosos dentro dos presídios. O conteúdo das cartas, segundo ela, voltava-se para maus-tratos sofridos dentro do presídio, num pedido de ajuda. Por não saber inglês, Léo me conta que nunca ficou sabendo do que realmente se tratavam as cartas. Entregou-as a mim e disse que eu teria material farto para entender um pouco o que se passava nos presídios onde ela trabalhava.

Durante nossas conversas, no entanto, pouco falamos de tais recortes de jornais. Estes documentos dizem respeito, antes, a um registro da história, essa história que, segundo Halbwachs (2006), se interessa pelo passado e não pelo presente, por aquilo que a memória já não fixa mais, e que por isso pode ser esmiuçado sem esbarrar na opinião 
alheia de então, sem despertar maiores emoções (Halbwachs, 2006:133). Os recortes de jornal trazidos por Léo fixam datas, estabelecem linearidade, fazem-na recordar o que aconteceu antes ou depois, auxiliam na construção de uma história passível de ser narrada de forma organizada, tornando-se assim compreensível. Os documentos que Léo me oferece são, possivelmente, os únicos marcos temporais exteriores, fixados objetivamente, que ela possui sobre sua trajetória profissional para além de seu prontuário, no qual ela encontra, também, as datas de cada transferência que vivenciou entre presídios paulistas.

Halbwachs (2006), ao trabalhar o conceito de memória coletiva e sua relação com o tempo, afirma que é apenas a partir do compartilhamento de certos estados de consciência individual de duração que somos capazes de criar marcos temporais. 0 tempo real, para o autor, é o tempo social, aquele em que se expressam as consciências coletivas. Em oposição ao tempo matemático - marcado por intervalos vazios de qualquer significado, não importando onde está o seu início - o tempo social é aquele em que é possível identificar diferenciações através do compartilhamento de consciências individuais. A distinção entre os momentos e os espaços vazios entre eles um tempo em que nada acontece - é o que possibilita, segundo o autor, o trabalho da memória. Neste sentido, a memória só se dá a partir da marcação de diferenças numa superfície lisa. Só assim um indivíduo, ou um grupo, pode identificar acontecimentos passados, pois eles se diferenciam uns dos outros numa linha do tempo: é possível, então, estabelecer o que veio antes, o que aconteceu depois etc. Esta diferenciação, no entanto, só pode acontecer de acordo com marcos externos à própria consciência:

Os homens concordam em medir o tempo através de certos movimentos que ocorrem na natureza, como os dos astros, ou criados e regulados por nós, como em nossos relógios, porque na sequência de nossos estados de consciência não conseguiríamos encontrar pontos de referência definidos suficientes que pudessem valer para todas as consciências (Halbwachs, 2006:116).

É nesse sentido que o trabalho da memória precisa de referências externas para que a consciência não se perca em estados abstratos e por demais subjetivos.

21 Ao se utilizar de recortes de jornais - referência objetiva - Léo estabelece marcos externos para uma experiência subjetiva calcada em referenciais pouco compartilháveis e apenas superficialmente objetiváveis, como a dor que reconhecia tanto nas experiências das presas quanto naquelas que ela própria vivenciava. Deixando os recortes de jornais de lado, Léo se baseia em experiências envoltas numa atmosfera densa de dor para ordenar a sua narrativa e dar, assim, sentido à sua trajetória profissional.

Os referenciais da memória de Léo voltam-se para experiências compartilhadas com as presas. Num cotidiano de convivência com tais mulheres, as quais muitas vezes ela chama de bandidas, são as histórias de dor - contadas, compartilhadas e vivenciadas que saltam da simples sucessão dos dias e ficam gravadas em sua memória. Todo o resto é cotidiano. Todo o resto é cenário para tais histórias. $\mathrm{O}$ dia a dia no cárcere, o abrir $\mathrm{e}$ fechar das celas, a contagem das presas, as conversas diárias, o cheiro da rua e o cheiro da cadeia, as desconfianças das presas, as desconfianças das guardas, as desconfianças da diretora, as desconfianças dos familiares, tudo isso não passa de elementos que colorem as histórias marcadas pela dor.

Os dias na prisão são uma sucessão de presas chegando e saindo, cumprindo penas longas ou curtas e, no intervalo, acontecimentos específicos saltam da sucessão dos dias 
e ficam guardados na memória de Léo. Diversas histórias em que a dor ofusca a capacidade da razão foram contadas por ela, numa busca para organizar a experiência e compartilhar a falta de sentido de uma trajetória marcada pela sucessão de histórias de tortura, de abandono, de descaso e de opressão.

A dor, dessa forma, toma lugar como o marco da memória, como aquilo que salta do cotidiano e possibilita, assim, uma organização da narrativa. Mesmo que a dor, por ser uma experiência em que duas consciências têm tão pouca possibilidade de se encontrar de forma objetiva, seja por si só difícil de ser compartilhada (Halbwachs, 2006), era a certeza de que eu compreenderia tais experiências - certeza de que a dor é, sim, algo passível de ser minimamente objetivo - que levou Léo a me contar sua trajetória.

A narrativa de Léo sobre as dores presentes no cárcere, no entanto, são construídas pelo trabalho do tempo. Num momento da vida profissional em que está contando os dias que ainda faltam para se aposentar, ela se volta para o início da carreira e faz, então, uma narrativa em que a experiência do outro - das presas, principalmente - é contada como parte da sua própria experiência. Veena Das (1999) aponta para a importância do trabalho do tempo na elaboração de narrativas sobre a violência. Eventos violentos raramente são interpretados e reelaborados no calor dos acontecimentos. A escrita destes textos, destas narrativas, é resultado de uma disputa de interpretações, todas baseadas na autoridade de seus locutores e, especialmente, no passar do tempo.

Há, porém, uma diferença fundamental entre a narrativa da violência coletiva - aquela que foi vivida por meio de experiências culturais compartilhadas - e aquela voltada para a experiência pessoal. Das aponta que a experiência individual da violência raramente é passível de se tornar narrativa, permanecendo na esfera do indizível: nem o tempo seria capaz de trazer uma compreensão compartilhada sobre eventos extremos vivenciados por uma pessoa. A narrativa de Léo pode ser interpretada na chave indicada por Veena Das. Já no final de sua carreira, ela é capaz de voltar e reinterpretar os acontecimentos violentos presentes em sua trajetória profissional, em geral envolvendo outras pessoas, trazendo para a sua história uma esfera de dor e horror. No entanto, quando se trata de elaborar a compreensão sobre as violências que a afetaram diretamente, Léo muda o tom da narrativa, recusando-se mesmo a falar sobre tais dores. A experiência própria permanece, nos termos de Das, indizíveis. Trabalharei mais à frente este aspecto do indizível e da experiência pessoal de Léo.

Segundo Halbwachs (2006), a dor é uma sensação pessoal e interna, real apenas no nível da consciência: tanto as dores físicas como as sensações no geral constituem ideias confusas ou inacabadas (2006:122). No entanto, a partir do momento em que descobrimos que esta dor pode ser causada por uma ação exterior, torna-se possível então imaginar como outras pessoas experimentariam a mesma sensação que sentimos. Este movimento de exteriorização é aquele que é chamado de representação objetiva da dor. Tal representação nada mais é que uma impressão coletiva, um amontoado de diversas consciências, e que, por si só, não deixa de ser também incompleta e truncada. Uma sensação tão íntima quanto a dor experimentada só pode ser compreensível na medida em que é compartilhada, já que esse seria o único caminho no sentido de uma exteriorização da dor:

Instintivamente procuramos e encontramos uma explicação inteligível deste sofrimento, com a qual os membros de um grupo concordem, da mesma forma com que o feiticeiro alivia o doente fazendo parecer que extrai de seu corpo uma pedra, uma velha ossada, um preguinho ou um líquido. Ou então despojamos o sofrimento 
de seu mistério descobrindo seus outros rostos, os que ele volta para outras consciências, quando imaginamos que pode ser experimentado por nossos semelhantes - nós o rejeitamos a um terreno comum a muitos seres e lhe restituímos uma fisionomia coletiva e familiar (Halbwachs, 2006:123).

\begin{abstract}
fato de compartilhar, ou ainda, de disputar versões dos acontecimentos violentos é o que possibilita uma organização da experiência violenta. Das afirma isto ao se voltar para as diversas histórias contadas sobre os eventos extremos ocorridos durante a Partição da Índia, no ano de 1947, em que mulheres foram raptadas e exiladas em função de uma disputa entre hindus e muçulmanos. Anos depois, os eventos ocorridos em tal época ainda são motivo de contenda narrativa. Mas é apenas a partir da construção de narrativas que os envolvidos no drama de então podem reorganizar a memória, elaborando versões e interpretações legítimas para os acontecimentos vividos. É o ato de narrar, portanto, que permite o compartilhamento de níveis subjetivos da experiência individual e coletiva. É possível perceber um movimento semelhante na narrativa de Léo, que encontra seu nível objetivo e objetificável desde o momento em que as experiências de dor e violência se tornam passíveis de serem compartilhadas.
\end{abstract}

\title{
A construção das narrativas e a dor
}

29 Na véspera do segundo turno das eleições presidenciais do ano de 1989, um grupo formado por homens e mulheres apareceu na mídia com camisetas do PT (Partido dos Trabalhadores). Este grupo era formado pela quadrilha que havia sequestrado o empresário Abílio Diniz, mantendo-o em cativeiro por seis dias. A cobertura da mídia, atrelando o sequestro do empresário à atuação do Partido dos Trabalhadores, teve consequências decisivas para o resultado das eleições presidenciais, já que depois de tais notícias os eleitores optaram por Fernando Collor de Mello, que estava em segundo lugar nas pesquisas eleitorais, em detrimento do candidato do PT, Luiz Inácio Lula da Silva. $^{2}$

30 Tal fato, conhecido, de certa maneira, pela população brasileira - já que se tratava da primeira eleição presidencial democrática após a ditadura militar - foi escolhido por Léo como primeiro marco da narrativa de sua trajetória profissional. Localizando o princípio de sua história em um fato amplamente conhecido, Léo deu início à narrativa de uma experiência marcada pela tortura, o que a leva diretamente para a esfera da dor.

31 Alguns jornais da época divulgaram, um dia depois do resultado das eleições (19 de dezembro de 1989), que os presos da quadrilha responsável pelo sequestro na verdade haviam sofrido tortura nas delegacias e teriam sido obrigados a vestir camisetas do Partido dos Trabalhadores, indicando um suposto envolvimento político no sequestro. Léo, por sua vez, conta que foi ela quem recebeu as duas mulheres que participaram do sequestro assim que chegaram ao presídio.

32 Antes da chegada das presas, Léo se lembra do quanto ficou tocada pela imagem do empresário veiculada pela mídia assim que saiu do cativeiro. Segundo ela, o homem se encontrava abatido, sabia-se que havia ficado dias em um quartinho minúsculo, ao som ininterrupto de um radinho. Para Léo, aquilo parecia desumano.

Anuário Antropológico, v.39 n.1 | 2014 
Outras imagens do ocorrido, no entanto, ficaram guardadas na memória de Léo. As presas estrangeiras chegaram ao presídio torturadas. "Elas estavam sem o bico do seio", Léo repetia, "estavam tão torturadas, estavam sem o bico do seio". Nesse momento, Léo parece se esquecer do que aconteceu do lado de fora do cárcere: empresário, radinho, camisetas do PT, nada mais tinha importância diante de um corpo tão torturado como o daquelas mulheres.

Esta foi a primeira história que Léo contou quando começou a falar sobre a sua trajetória, dizendo que isto ocorreu assim que ela entrou para trabalhar no presídio. Não importa muito se o fato aconteceu no primeiro, no segundo, ou no terceiro ano de profissão. Esta é a história número um, o mais antigo e importante evento que marca a trajetória profissional de Léo.

Outras histórias, no entanto, povoaram as narrativas de Léo.

\section{Um quarto muito escuro}

Ivonete não foi a primeira presa a surtar na cadeia desde que Léo havia assumido o posto de guarda. Os surtos, à sua maneira, eram comuns, e não era o olhar de louca da presa o que tocava Léo, nem mesmo seus gritos agonizantes de terror. Era o abandono a que a presa era relegada, era o seu poder de autodestruição, eram os cortes na pele, a escuridão e a solidão da cela do castigo que moviam Léo na direção daquela presa interditada.

Essas eram as regras da cadeia, Léo bem sabia: bandida em castigo deve ficar incomunicável, deve sofrer, deve lidar com as próprias necessidades, com os próprios dejetos, deve se virar para tomar banho na privada, deve aprender a tratar de si mesma. Ivonete, no entanto, não conseguiu. 0 que conseguiu foram cortes cotidianos na pele: primeiro um arranhão no braço, depois outro no outro braço. Os cortes começaram a ficar mais fundos, ela já não sabia há quanto tempo estava no castigo.

8 Era Léo, do lado de fora da cela, quem contava os dias. Ainda restava uma semana de castigo e ela temia que a presa não suportasse. Pela portinhola da cela, Léo observava os cortes, ouvia seus gemidos, imaginava a sua dor. Sabia que ela, também, estava sendo observada, que não poderia intervir, que a presa deveria ser abandonada à própria sorte. Presa em castigo merece o próprio sofrimento. Castigo para a presa, castigo para Léo. Enquanto a presa gemia na cela, Léo só fazia pensar em formas possíveis de aliviar um mínimo do sofrimento cotidiano daquela que poderia, por um motivo qualquer do destino, ser ela mesma.

Quando Léo percebeu que seu próprio limite estava prestes a estourar, não suportando mais os gemidos de Ivonete, quando a loucura e a dor da presa estavam prestes a se tornar a sua própria loucura e a sua própria dor, sentiu então que algo havia rompido dentro de si: ainda faltavam quatro dias de castigo e Léo trouxe de casa, sob a roupa, em pequenas trouxinhas, gases e porções mínimas de iodo em vidros diminutos.

Durante a troca de turno, Léo se demorava um pouco e, nos breves minutos em que a outra guarda responsável pelo pavilhão se afastava, ela chamava a presa para perto da portinhola, metia as mãos para dentro da cela, embebia os pequenos pedaços de gaze no pouco líquido que trazia consigo e, às cegas, espalhava iodo pelo corpo da presa, que não dizia nada, não se movia, mas sabia, de maneira grave, que estava sendo cuidada por aquela que também vigiava a porta de sua loucura. 
41 Findo o castigo, a presa saiu da cela amarelada pelo pouco sol e pelo muito iodo. As feridas já cicatrizadas, o cabelo tomado por piolhos, os olhos ausentes. Enviada para a enfermaria, Léo não precisaria mais vigiá-la nem cuidar mais dela. Ivonete, no entanto, fincou raízes na alma de Léo, que percebeu, como num estalo, que poderia dali para frente cuidar da dor daquelas que estavam tão perto de si, mesmo que a cadeia dissesse a ela que isto era terminantemente proibido.

42 A trama das histórias de dor narradas por Léo envolvem, na maioria das vezes, elementos de luta contra o sistema prisional. Como no trecho acima, em que reconstruo uma destas histórias, retratando não apenas a ação em si, mas os elementos afetivos e sensitivos presentes na fala de Léo, os relatos que escolheu para me contar são carregados de símbolos de revolta e luta contra a opressão sofrida dentro do cárcere. Ao contar a sua história a partir de histórias de dor das presas com quem conviveu, Léo traça uma trajetória em que a militância em favor dos direitos humanos vai se delineando e tomando a dianteira da própria ação.

43 A partir da história das chilenas sequestradoras, Léo dá início a uma narrativa dura, em que, como mostrei no trecho acima, começa a realizar um trabalho de cuidado dessas presas. Tal postura, no entanto, não foi imediata: assim que começou a trabalhar no presídio, ela temia o envolvimento com as presas, os olhares das outras guardas, ter que ser disciplinada por não cumprir estritamente as regras repassadas. Tais regras visam, antes de mais nada, a uma distância que deve ser mantida entre o grupo de guardas e o de presas. Qualquer envolvimento mais próximo pode ser interpretado como traição, aquilo que pode facilitar fugas ou, ainda, como corrupção. Com regras explícitas como essas, ${ }^{3}$ uma postura que privilegiasse o cuidado com as presas era algo perigoso.

O primeiro posto assumido por Léo, assim que tomou posse na função de agente de segurança penitenciária, foi na inclusão - um local de triagem das presas que estão chegando ao presídio. É ali que se dão os primeiros procedimentos, assim como são repassadas as primeiras instruções para as presas. As guardas alocadas em tal função devem, além de guardar os pertences que cada presa trouxe consigo, ler o processo de seu julgamento para saber por qual tipo de crime está cumprindo pena e, assim, poder encaminhar cada uma delas para um pavilhão adequado.

Este foi, segundo Léo, o primeiro contato que tomou com os crimes cometidos pelas presas. Ela deveria saber os motivos pelos quais tais mulheres estavam cumprindo pena. Logo, antes de conhecer as detentas, Léo conhecia seus crimes. Num segundo momento, quando ela passou a trabalhar no pavilhão em contato direto com as presas, foram as histórias contadas por elas para justificarem seus crimes o que preenchia o cotidiano.

Ao conviver diretamente com as detentas e suas histórias, Léo começou a perceber que, apesar do crime cometido, havia ali um ser humano também passível de sentir dor. Para além do que havia acontecido fora do presídio e dos motivos que tinham levado essas mulheres a serem enclausuradas, Léo detectava um cotidiano marcado por opressão - opressão esta vinda do sistema prisional tanto quanto das outras presas e das guardas.

Era de amplo conhecimento entre as funcionárias do presídio que a proximidade entre guardas e presas era mal vista pelo sistema prisional. Neste sentido, estender a mão para cuidar da dor de uma presa era algo proibido. Aos poucos, no entanto, Léo foi ganhando confiança em relação à sua própria postura, ao perceber que era possível 
cuidar das presas sem se igualar a elas, sem negociar com elas. A aprendizagem da carreira volta-se para um estado de equilíbrio entre o sim e o não, entre o permitir e o proibir. ${ }^{4}$ Foi apenas quando Léo se sentiu segura nesse equilíbrio tênue, nessa relação delicada e tensa ao mesmo tempo, que pôde dar início a um trabalho árduo de cuidado das presas. Foi só então que Léo começou a levar vidrinhos de iodo escondidos na roupa para poder cuidar de presas que julgava estarem sendo oprimidas pelo sistema prisional, torturadas, maltratadas por um estado que deveria, antes, cuidar delas.

Outros relatos de dor e de militância começam a preencher a fala de Léo. Aos poucos, ela oferece um leque de pequenas histórias a partir das quais consigo perceber que é a capacidade de sentir dor o que gera uma identificação dela em relação às detentas: ${ }^{5}$ uma camponesa de 79 anos que ficou detida por tráfico de drogas e não pôde ser levada ao convívio com as outras presas, já que estava doente em fase terminal, e que quedou por meses na enfermaria do presídio; uma presa estrangeira que sofreu uma morte misteriosa, cujas correspondências eram barradas pelo diretor que também proibiu as guardas de prestarem ajuda; uma mãe de santo que foi presa por ter participado de um ritual onde crianças foram mortas; uma chinesa que, segundo Léo, sofria de "mongolismo" e foi presa por roubar um frasco de perfume numa farmácia.

Através dessas histórias, Léo vai me explicando como o sistema prisional funciona, como ele segrega certas pessoas e lhes retira qualquer possibilidade de defesa; como, apesar das leis que protegem os presos, os/as guardas e dirigentes dos presídios agem à revelia das mesmas, criando regras próprias dentro do cárcere, garantindo sua autonomia a partir da sombra que lançam sobre a realidade prisional. ${ }^{6}$ Para além desta aula sobre a instituição prisional e o seu funcionamento, as histórias contadas por Léo me ajudam a compreender a maneira como ela lida com esse sistema, e as estratégias que utiliza para sobreviver a ele, assim como os elementos capazes de gerar identificação e distância entre ela, as presas e as demais guardas.

\section{Suzane versus Andreia}

De todas as histórias que Léo me contou, em apenas uma ela se colocou numa postura contra a presa: foi o caso de Suzane Von Richthofen. ${ }^{7}$ Diferente de outros casos, Léo não precisava me contar a história de Suzane, não precisava relembrar qual o crime cometido por ela, já que o caso foi amplamente divulgado na mídia brasileira. Ela me dizia que matar pai e mãe é algo horroroso, "uma pessoa assim não merece perdão". Léo relembrava que Suzane é ré confessa, que assumiu perante o tribunal a participação no assassinato. Em função das minúcias do crime, Léo afirmava que Suzane não merece viver em sociedade.

51 Esta certeza - a de que Suzane não merece viver em sociedade - não vem apenas do crime cometido, mas principalmente do convívio que Léo teve com ela. "Ela é manipuladora, ela acha que pode tudo com aquela cabeça, ela é muito inteligente, ela tentava se utilizar da minha homossexualidade para conseguir o que ela queria". Pelo clamor popular que seu crime suscitou e pela natureza do que havia cometido parricídio - Suzane não poderia ficar no convívio com as demais presas, já que seria maltratada ou, ainda, poderia ser morta pelas demais detentas. Por isso, enquanto esteve presa onde Léo trabalhava, Suzane ficou todo o tempo detida na enfermaria, protegida assim do contato com as outras presas. 
52 Algum tempo depois, durante nossas conversas, Léo se lembrou do caso de Andreia, outra presa que foi condenada por ter assassinado o pai e a mãe. Ao contrário de Suzane, Andreia foi colocada direto no convívio com as outras presas e teve sua mão tatuada por elas com o crime que cometeu: "matei meu pai e minha mãe". Léo conta que Andreia foi cruelmente torturada pelas detentas, e me dizia: "Imagina uma pessoa que sabe que está chegando a hora de apanhar, porque ela apanhava todo dia, no mesmo horário; quando chegavam as 10 horas, ela sabia que estavam vindo para bater nela". Eram as presas que decidiriam quando chegaria o fim de sua pena, quando seria o momento em que, de tanto apanhar, teria pagado o crime cometido.

Diferente de Suzane, Andreia não foi protegida pelo Estado e ficou à mercê das demais presas. Léo, então, se compadeceu do estado de Andreia e se esforçou para cuidar dela, procurando oferecer, à sua maneira, a proteção que o Estado lhe negou. A dor de Andreia - que era torturada diariamente - atingiu Léo. Quando perguntei a Léo o que havia de diferente entre as duas, querendo saber qual o motivo pelo qual se identificava com Andreia, compadecendo-se da sua dor, enquanto acreditava que Suzane, apesar de ter cometido o mesmo crime - imperdoável, segundo Léo - não deveria voltar ao convívio com a sociedade, Léo me respondeu que diante do sofrimento de Andreia, do corpo torturado, ela esquecia qual o crime que fora cometido.

Andreia sofreu. Suzane, para Léo, não sofreu. Suzane foi protegida pelo Estado e continuava sua carreira manipuladora. Andreia foi largada à própria sorte em meio às presas furiosas em face do crime que tinha cometido. A dor de Andreia tornava-a humana para Léo, o que não aconteceu com Suzane:

Quando eu descobria, era engraçado, porque lá dentro, pra mim, era outra pessoa. Eu tinha tanto dó de saber que a Andreia apanhava, eu esquecia que ela tinha matado pai e mãe, ali eu convivia com a dor da Andreia, e a Andreia era frágil.

Isto não significa que Suzane deveria ser torturada. Em momento algum Léo esboçou qualquer opinião neste sentido, sendo que, no caso de Suzane, o Estado cumpriu o dever de garantir a sua segurança no presídio, o que não ocorreu com Andreia, que também deveria ter recebido o mesmo tipo de proteção. No entanto, o que se percebe é que a dor que uma presa é capaz de sentir se sobrepõe ao horror do seu crime aos olhos de Léo. $O$ único elemento de identificação entre Léo e as mulheres que custodiava era a dor. Na ausência de dor, ela se via completamente diferente, mesmo que as origens sociais, o nível educacional, ou qualquer outro elemento as tornassem parecidas. ${ }^{8}$

\section{Lutando contra o "sistema" - os "bondes", as revoltas e 0 adoecimento}

57 Apesar de fazer parte do corpo funcional do sistema prisional, ao longo de sua carreira Léo vai criando uma identidade de oposição à instituição. Os limites de sua luta são definidos a partir do próprio sistema prisional. No entanto, em alguns momentos, Léo legitima o sistema: como no caso de Suzane Richthofen, em que a pena de prisão é percebida como útil para proteger a sociedade da convivência com esse tipo de "criminosa".

58 A identidade de Léo enquanto profissional vai se colando à sua trajetória de luta a favor dos direitos de presos e presas. No entanto, como foi dito por ela certa vez, o preso só existe dentro das grades, o que faz com que o significado da vida de Léo se encontre 
também dentro das grades. Se o presídio deixa de existir, o sentido da experiência de Léo se desvanece. A sua identidade é criada e mantida na luta contra o "sistema". ${ }^{9}$

A postura de luta foi se desenhando mais claramente a partir do momento em que Léo passou a manter contato mais próximo com grupos militantes de direitos humanos. No princípio, a ligação com tais grupos era extremamente velada, num esforço de manter em sigilo a sua postura de cuidado e atenção com as presas, evitando assim criar problemas com a instituição. Com o decorrer dos anos, porém, Léo vai se tornando confiante a ponto de avaliar o sistema como "burro", ou seja, segundo ela, ele não percebe quem está agindo em seu interior.

Essa percepção se volta para a aparente falta de punição que sofreu por parte da instituição, apesar de ter realizado diversas denúncias. O que ela chama de sistema "burro" nada mais é que uma instituição que pune disciplinarmente os presos problemáticos, mas dá um outro tipo de castigo - muito mais velado, muito mais sutil aos funcionários tidos como indisciplinados. Por estar acostumada com as punições voltadas para os presos, Léo não identifica as estratégias da instituição para barrar os funcionários transgressores como de fato uma punição. Tais estratégias são percebidas por ela, antes, como estratégias de luta, tanto suas quanto do "sistema".

\section{Punição exemplar}

\section{Cena 1}

61 Um pouco antes de chegar em casa, Léo percebeu que a lanterna já iluminava pouco. Pilha porcaria essa que ela tinha comprado. Se quisesse voltar ao presídio na noite seguinte, no mesmo horário, para conseguir novos documentos, deveria comprar pilhas novas. Sem problemas. As pilhas eram o de menos.

62 Ao abrir a porta do apartamento, sentou direto no chão da sala, arrancou da cintura um punhado de papéis e espalhou todos pelo chão. Eram cartas, documentos de transferência, fotografias, tudo o que ela tinha conseguido roubar da gaveta do diretor naquela noite. Havia também notas, alguns contratos. Separou os documentos por categorias, talvez houvesse ali alguma coisa boa, alguma prova de corrupção. Voltaria na noite seguinte ao presídio para devolver os documentos já copiados e procurar outras provas, qualquer coisa que pudesse derrubar o diretor. Era noite de sexta, ele só voltaria ao presídio na segunda, ela teria ainda dois dias para terminar o trabalho.

63 Na noite seguinte, dirigiu-se novamente ao presídio, com entrada facilitada por aqueles que admiravam a sua audácia, mas não tinham, nem de longe, a mesma coragem. No escuro da cadeia, Léo, com sua lanterna e pilhas novas, dirigiu-se sem dificuldades, mais uma vez, à sala do diretor. Mais uma vez encontrou a sala escura e vazia, devolveu os documentos da noite anterior, vasculhou outra gaveta e outro armário, baixou mais uma vez o gorro cobrindo todo o rosto e saiu às pressas do presídio.

Tudo se passou como num filme. A diferença é que nem mesmo na terceira noite de ação houve qualquer pessoa na sala do diretor para acender a luz e dar um flagrante em Léo.

\section{Cena 2}

- Poxa, Léo, dessa vez você pegou pesado, hein? 
- Ah, vai, não vai me dizer que agora você vai ficar chateada só porque eu te chamei de sapatão enrustida...

- Mas precisava pegar tão pesado?

- A gente conseguiu o que a gente queria, não conseguiu? Você foi lá e conseguiu encontrar o porão, do jeitinho que eu te falei, não foi? E melhor, ninguém desconfiou que fui eu quem fez a denúncia pra você, os caras têm certeza que eu te odeio, que eu odeio todo o povo dos direitos humanos.

- Puxa, e encontrar aquelas presas lá, torturadas, escondidas naquele alçapão, isso é uma barbaridade.

- Agora imagina a minha vida, nega, sabendo disso todos os dias, acompanhando, e não podendo fazer nada! E se eles descobrem que fui eu quem falei o local pra você? - É, depois do que você disse, do jeito que você falou comigo, acho difícil eles acharem que foi você...

- E o que vai acontecer agora?

- Agora tá nas mãos do Ministério Público, a Pastoral já encaminhou a denúncia formal, é bem provável que o diretor caia depois disso tudo.

- E eu?

- Pode ficar tranquila, ninguém sabe que foi você.

\section{Cena 3} menos de trabalho pago. barata. cárcere.
Como de costume, Léo chegou um pouco antes das 7 da manhã ao presídio onde trabalhava. Esperou cinco minutos no portão e entrou para começar mais um dia de trabalho. Ainda trazia no rosto um resquício de esperança, uma alegria contida pela denúncia finalmente feita na semana anterior, pelo processo ao qual o diretor responderia. Ela havia vencido, certamente havia vencido.

Distraída em pensamentos de esperança, não percebeu a guarda da portaria dizendo que ela não poderia entrar. "Você foi transferida para a $\mathrm{PFC}^{10}{ }^{10}$ foi o que a guarda disse. Léo deu mais um passo e foi quando percebeu que a guarda se colocou no seu caminho. o que houve, querida? A resposta foi a mesma. Ela havia sido transferida para a Penitenciária Feminina da Capital. E é melhor se apresentar lá hoje, senão é um dia a

Do Tatuapé até Santana ${ }^{11}$ ela não gastaria muito tempo, daria ainda para aproveitar o dia. Quando se apresentou na PFC, entendeu o recado: ela não era bem vinda. 0 máximo que Léo conseguiu foi ficar no estacionamento. Passaram-se meses, durante os quais ela revisou mentalmente cada denúncia, cada acontecimento, cada palavra do diretor. Ao final de 11 meses conseguiu entrar no presídio novamente. Trazia nas mãos um mandado de segurança, e no banco uma dívida considerável - advogado não é coisa

As três cenas descritas acima apontam para formas específicas de Léo se relacionar com o sistema prisional. A primeira ilustra uma estratégia de ações clandestinas contra a instituição, ressaltando a maneira como tais ações passam, a princípio, despercebidas. $\mathrm{Na}$ segunda, o diálogo retratado indica estratégias de acobertamento das relações que Léo mantinha com os militantes de direitos humanos: na frente das outras guardas, ela se mostrava veementemente contra essas pessoas, sendo que na verdade era ela quem levava as denúncias para tais grupos e garantia, assim, que as informações sobre aquilo que acontecia dentro do presídio chegassem até o Ministério Público e algo fosse feito para punir os responsáveis pelas torturas e os maus-tratos que aconteciam dentro do 
69 Nas duas primeiras cenas é possível notar estratégias de atuação contra a instituição prisional de forma que Léo não fosse punida. E, de fato, ela nunca foi punida formalmente por isso. Por muito tempo chegou a acreditar que a instituição não percebia aquilo que ela estava fazendo. o que Léo não sabia, no entanto, é que essa instituição contra qual ela lutava possuía outros meios de punir os funcionários "rebeldes".

70 É a partir de uma série de transferências entre presídios, os chamados bondes, que Léo vai, aos poucos, sofrendo outros tipos de punição por parte da instituição. De acordo com a sua fala, as transferências entre unidades prisionais aconteciam sempre depois que alguma denúncia contra a instituição havia sido feita, fosse ela a responsável ou não, fosse uma denúncia formalizada por ela mesma, por instituições que trabalham em prol dos direitos humanos dos presos e das presas, por algum jornalista ou pelo Ministério Público. A instituição, que ela chamava de "burra", sabia bem por onde vazavam as informações. E a sua forma de punir não era pelo castigo físico, nem mesmo pelo enclausuramento, mas pelo desenraizamento ou pela segregação.

71 Ao entrar novamente no presídio, depois dos 11 meses impedida de trabalhar, como foi retratado no trecho acima, as coisas não foram fáceis para Léo. Mesmo depois de tanto tempo distante, ela ainda sentia que era percebida como um risco para a instituição, já que poderia ser reconhecida pelas colegas de trabalho como uma guarda que conseguira se colocar contra o sistema prisional. A instituição precisava, de alguma forma, neutralizá-la. As estratégias usadas pela diretoria, segundo Léo, voltavam-se para a alocação de funcionários "problemas" em postos isolados, como nas guaritas de vigilância (hoje um cargo específico chamado AEVP - agente de escolta e vigilância prisional) ou na portaria.

É a partir de episódios como esse, em que Léo ficou afastada do presídio e da possibilidade de exercer a sua função, que ela identifica o seu próprio processo de adoecimento. Diferente de outras guardas, a narrativa de Léo aponta para uma trajetória que revela momentos de doença que não estão ligados a uma separação frágil entre a realidade do cárcere e a existente fora dele, ${ }^{12}$ mas a um enfraquecimento em face das investidas da instituição contra o trabalho que ela vinha realizando em favor dos direitos das presas.

\section{O Primeiro Comando da Capital: desilusão, frustração e delírio}

Desde o segundo encontro que tive com Léo, em que ela trouxe recortes de jornais, a presença do Primeiro Comando da Capital - PCC mostrou-se forte em sua fala. Já ali Léo afirmava que não dá para pensar na identidade do guarda de hoje sem pensar na presença deste grupo nos presídios paulistas. Sua narrativa sobre a própria trajetória profissional e também as suas ponderações sobre a profissão de agente de segurança penitenciária são divididas temporalmente pelo surgimento do PCC e o domínio que tal coletivo de presos passou a exercer dentro dos presídios paulistas. o primeiro esforço, na fala de Léo, volta-se para a legitimação do grupo enquanto realidade no sistema prisional. Os recortes de jornais trazidos por ela apontam para uma resistência do governo do estado de São Paulo em reconhecer a sua presença no interior dos presídios, negando assim uma suposta falta de controle do estado sobre a realidade prisional. 
74 A postura de Léo, de legitimação do PCC, diz respeito a uma denúncia contra o Estado, que se recusa a olhar para o sistema prisional ${ }^{13} \mathrm{e}$, principalmente, a agir de forma a punir aqueles presos que, na visão dela, estão oprimindo outros presos. ${ }^{14}$ Apesar de ter trilhado uma carreira voltada para o cuidado e a garantia dos direitos dos presos, Léo, em momento algum, passa para o "lado de lá", ou seja, mesmo agindo em prol dos presos, ela não se identifica com eles, não ultrapassa as regras de forma a privilegiar uma vida "bandida". É diante do PCC e da sua expansão dentro dos presídios paulistas que Léo se reafirma como uma guarda justa e "decente", que não negocia com os presos, apesar de lutar pelos seus direitos.

Foi a partir de um conflito envolvendo possíveis relações com o PCC que Léo sinalizou o momento mais difícil de sua carreira, numa situação que ela acredita ter quase ultrapassado o limite da loucura. Depois de ter realizado muitas denúncias contra o sistema prisional, ela se tornou uma guarda visada pela instituição. Ela era, portanto, vigiada, e sentia que os diretores e os responsáveis pelo Sistema Prisional estavam apenas esperando qualquer erro de sua parte para poder prejudicá-la. Segundo ela, sua vida era uma eterna espera por uma "cama de gato". Um dia, a cama de gato chegou.

Depois de ter sofrido uma transferência, Léo assumiu o posto na nova unidade prisional durante o final de semana. Quando se apresentou para trabalhar, percebeu que o presídio estava esvaziado de funcionários e, com isso, ela, sozinha, não conseguiria dar conta de toda a tarefa de vigília e também de alimentação das presas. Em face deste cenário, Léo avisou às detentas que não poderia "pagar" o almoço delas, tampouco concederia o banho de sol. Depois de explicar às presas a situação, elas, por sua vez, resolveram se rebelar, tomando Léo como refém para que o diretor da unidade aparecesse no presídio e resolvesse a situação.

Nada aconteceu com Léo. Ela não foi, em momento algum, prejudicada pelas presas. 0 diretor do presídio chegou, fez as negociações cabíveis e, no mesmo dia, algumas internas foram transferidas para outro presídio, conforme a reivindicação do coletivo. Como Léo era a única guarda de plantão, assim que foi libertada da rebelião ela se encarregou das transferências.

Dias depois, Léo soube que estava sendo acusada de ter organizado a rebelião. 0 estranho, para quem estava de fora, era saber que ela tinha sido feita refém, depois liberada e ainda se encarregara das transferências, que eram, por sua vez, reivindicação das presas. Como ela poderia ter sido feita refém e, ainda assim, atuado em prol das presas no momento das transferências? Na visão dos dirigentes do presídio, isto era subversão. Léo passa então a ser acusada de traição, por ter enquanto guarda incitado uma rebelião, organizado um conflito contra o próprio Estado.

Esta foi a acusação feita pelos dirigentes. Há ainda a versão do PCC, que se incomodou com o fato de uma guarda que não era batizada no partido ${ }^{15}$ ter organizado uma rebelião num presídio que estava sob o comando da organização. Com isso, a líder do coletivo naquela unidade foi acusada pelos seus líderes, e passou, assim, a responder por contravenção a partir das regras do PCC. Esta presa procurou Léo e pediu a ela que esclarecesse o ocorrido com a "torre" do partido (forma como os líderes da organização são chamados), afirmando para eles que fora ela, a presa, e não Léo quem organizara a rebelião. Léo não achava justo que a presa fosse condenada pelo PCC, assim como não achava justo tomar para si a responsabilidade por um ato que ela considerava abjeto: traição. 
80 Para resolver a situação, Léo pediu à presa que passasse o recado para a "torre" e que eles fizessem uma ligação para o presídio. o diretor, já avisado, assim que recebeu a ligação, chamou Léo. Falar com a "torre", no entanto, não era algo simples para ela: conversar com aquela que ela considera uma facção criminosa, ter de dar explicações a tal grupo era, para Léo, legitimar seu poder dentro dos presídios e sobre os guardas em geral. Ter que dar satisfações a um preso, e não ao Estado, foi algo que causou profunda revolta nela, mas o fez apenas para proteger a presa.

81 A situação com o PCC foi resolvida. Os diretores que procuravam acusar Léo de subversão não o fizeram por falta de provas e, com isso, ela não foi acusada formalmente. No entanto, os problemas não foram resolvidos ali, já que as suspeitas dos colegas sobre o seu envolvimento com o PCC perduraram. Suspeitas que ela não poderia combater, já que não foram feitas formalmente.

82 Esta é a versão de Léo sobre o que aconteceu no dia da rebelião na unidade prisional e seus desdobramentos posteriores. Para ela, mais importante que as acusações formais foram as interpretações que seus colegas fizeram sobre a sua conduta - uma postura que ela construiu ao longo de toda a sua carreira, reivindicando para si o status de guarda justa. Nesse período, os colegas de Léo passaram a evitá-la. Dentro do presídio quase ninguém conversava com ela. Ela é, então, alocada para trabalhar na torre da muralha, espaço diminuto em que o guarda passa o dia inteiro sozinho, e não pode sair nem mesmo para ir ao banheiro.

83 Enquanto se encontrava bastante sozinha, Léo tentava organizar os eventos em sua mente, procurando compreender a sequência dos fatos, a maneira como se deu aquele desfecho em que ela se sentiu acusada de um crime que não cometeu - traição. Foi ali, sozinha, na torre da muralha, que Léo se sentiu próxima da loucura, já que se envolvera numa atmosfera de revolta, frustração e, principalmente, vergonha dos olhares dos colegas que a acusavam. Léo passou dias sem conversar com ninguém, não se alimentava mais, já que não conseguia enfrentar os olhares dos colegas durante as refeições.

84 Léo conta que se encontrava então no limiar da loucura, não sendo mais capaz de diferenciar as horas, os momentos de solidão e, em especial, as lembranças dos ocorridos recentes e antigos. Aos poucos, ela vai se mutilando, cortando um pouco do cabelo a cada dia. Depois de algum tempo, foram os militantes de direitos humanos que se inteiraram de sua situação e procuraram ajuda médica para ela. Aos poucos, ela foi se reabilitando e voltou a trabalhar nos presídios.

85 Hoje, Léo está alocada num presídio semiaberto, em que o trabalho é bem mais tranquilo e não há uma estrita vigilância sobre as presas. Ela pontua que atualmente é muito difícil realizar o trabalho que sempre exerceu nos presídios, já que a presença do PCC impede qualquer tipo de atuação. Para ela, a impossibilidade de tal trabalho faz com que a profissão perca seu sentido, pois sabe que continuará vendo presas maltratadas sem, no entanto, poder agir como fazia antigamente. Agora, são as próprias presas que recusam qualquer cuidado.

86 Antes Léo lutava contra uma instituição que ela avaliava como opressora, e essa instituição era o Estado que a empregava. Hoje, a sua luta teria que se voltar contra uma organização que considera criminosa, que pouco conhece, que pouco se sabe sobre ela, que atua de forma ainda desconhecida e que, de acordo com ela, é muito mais opressora que o próprio Estado. Diante dessa realidade, Léo preferiu, depois de tantos 
anos trabalhando e militando dentro do sistema prisional, se afastar, atuando em presídio em que não existem presas maltratadas. Com isso, ela evita conviver com a dor que sempre a acompanhou em sua carreira, porque agora, depois de tanto tempo lutando, ela não consegue fazer mais nada. E por isso entende que não é mais possível ser guarda. prisional brasileira. Num primeiro momento, é possível compreender alguns dos desafios vivenciados pelos profissionais que atuam dentro dos presídios a partir da chave da experiência. O relato de Léo e as construções narrativas elaboradas por ela permitem compreender a maneira como tal experiência é interpretada pelo sujeito e, depois, reelaborada no nível da narrativa. É importante ressaltar, na esteira de Veena Das, a distância temporal que separa a experiência de sua narrativa. Molloy (2004), ao trabalhar a escrita autobiográfica na América hispânica, aponta o quanto a escrita de vida, ou seja, o exercício de narrar a vida a partir de um exercício da escrita, é marcado por uma ruptura do sujeito com o solo empírico. Léo é capaz de contar a sua história e a história daquelas com quem conviveu por quase 30 anos no sistema prisional porque já se encontra em solo distante daquele onde as histórias ocorreram. Narrativa e experiência ligam-se intimamente - só há narrativa onde ocorreu a experiência - mas jamais se encontram no mesmo espaço temporal.

ativas de Léo, como a de outras agentes prisionais que participaram da pesquisa realizada, e também de tantos funcionários que relatam suas histórias a outros pesquisadores, permitem um conhecimento sobre o cárcere que ultrapassa os dados institucionais disponibilizados pelas agências do estado de São Paulo. A partir daquilo que Léo conta sobre a prisão, temos acesso não apenas a mais um olhar sobre ela nesse momento, o olhar da agente prisional - mas também um olhar voltado para a experiência, o que extrapola a ideia de mais um ponto de vista. Através das narrativas de Léo é possível conhecer o encontro entre vários grupos dentro do cárcere e as consequências desse encontro para cada um deles. A fala de Léo revela, portanto, uma multiplicidade de vozes e de formas de experimentar a vida na prisão.

90 Para além da esfera da experiência no cárcere, as narrativas de Léo também apontam para a possibilidade de pensar no compartilhamento da dor como algo que constrói narrativas, ou seja, em pensar a dor como uma experiência passível de ser compartilhada, mas que o é apenas narrativamente. A experiência indizível, como alude Veena Das (1999), torna-se dizível na narrativa a partir da convicção de que ela pode ser compartilhada. Narrar as dores do cárcere transforma-se, assim, em uma tarefa compreensiva: narrar para compreender, compreender para reelaborar, reelaborar para passar a limpo. O eterno trabalho da reescrita, como dizia Veena Das sobre as narrativas indianas sobre a Partição.

91 Nesse sentido, a narrativa de uma mulher sobre o cárcere não aponta apenas para a experiência individual. Ainda que Léo seja conhecida e reconhecida por seus pares como uma agente prisional fora do comum, com uma experiência profissional bastante diferente daquela de muitas outras guardas, ainda assim sua narrativa não aponta apenas para si, e a análise realizada informa muito mais do que só sobre a vida ou os desafios de um indivíduo. Léo não é representativa dentro de um grupo, suas experiências são mais distintas do que semelhantes em relação a seus pares, mas sua trajetória e a maneira como ela escolhe para narrá-la nos informam sobre uma

Anuário Antropológico, v.39 n.1 | 2014 
instituição - o Sistema Prisional - uma profissão - agente de segurança penitenciário e, principalmente, sobre a experiência vivenciada dentro dos muros da prisão no seu trânsito constante entre as muralhas que pretendem separar tudo quanto acontece ali dentro das relações vivenciadas fora do cárcere.

\section{BIBLIOGRAFIA}

BIONDI, Karina \& MARQUES, Adalton. 2010. "Memória e historicidade em dois "comandos" prisionais". Lua Nova, São Paulo, 79:39-70.

CASTRO E SILVA, Anderson Moraes. 2008. Nos braços da lei. O uso da violência negociada no interior das prisões. Rio de Janeiro: e+a.

DAS, Veena. 1999. "Fronteiras, violência e o trabalho do tempo: alguns dilemas wittgensteinianos". Revista Brasileira de Ciências Sociais, 14 (40): 31-42.

FELTRAN, Gabriel. 2010. "Margens da política, fronteiras da violência: uma ação coletiva das periferias em São Paulo”. Lua Nova, São Paulo, n. 79:201-233.HALBWACHS, Maurice. 2006. A memória coletiva. São Paulo: Centauro.

GINZBURG, Jaime. 2000. “Notas sobre elementos de teoria narrativa”. In Rildo Cosson (org.). Esse Rio Sem Fim - Ensaios sobre Literatura e suas fronteiras. Pelotas: UFPEL. pp. 113-136.

GODOI, Rafael. 2010. Ao redor e através da prisão: cartografias do dispositivo carcerário contemporâneo. Dissertação de Mestrado em Sociologia, Universidade de São Paulo.

MARQUES, Adalton. 2009. Crime, proceder, convívio-seguro: um experimento antropológico a partir de relações entre ladrões. Dissertação de Mestrado em Antropologia Social, Universidade de São Paulo. MOLLOY, Sylvia. 2004. Vale o escrito. A escrita autobiográfica na América hispânica. Argos: Chapecó. PADOVANI, Natália Corazza. 2014. "Confounding borders and walls. Documents, letters and the governance of relationships in São Paulo and Barcelona prisons”. Vibrant, 10 (2):340-376.

SABAINI, Raphael. 2012. Uma cidade entre presídios: ser agente penitenciário em Itirapina - SP. Dissertação de Mestrado em Antropologia Social, Universidade de São Paulo.

SALLA, Fernando. 2006. “As rebeliões nas prisões: novos significados a partir da experiência brasileira”. Sociologias, Porto Alegre, ano 8, 16:274-307, jul./dez.

SINHORETTO, Jacqueline, SILVESTRE, Giane \& MELO, Felipe. 2013. "O encarceramento em massa em São Paulo”. Tempo Social - Revista de Sociologia da USP, 25 (1):83-106.

TAETS, Adriana R. F. 2012. Abrindo e fechando celas: narrativas, experiências e identidades de agentes de segurança penitenciária femininas. Dissertação de Mestrado em Antropologia Social, Universidade de São Paulo.

TAVARES DOS SANTOS, José Vicente. 2009. Violências e conflitualidades. Porto Alegre: Tomo Editorial.

\section{Jornais consultados}

Estado de São Paulo, Cidades/Metrópole, 14/10/2008. 
Folha de São Paulo, Cotidiano, 28/11/2005 e 29/11/2005.

http://www1.folha.uol.com.br/folha/cotidiano/ult95u124232.shtml, Folha.com, Cotidiano, 22/07/2006. Acesso em: 29/12/2011.

\section{NOTAS}

1. Pesquisas recentes sobre o cárcere e suas relações com o exterior apontam para aspectos significativos sobre a porosidade que atravessa os muros da prisão. Para isto, ver Padovani (2014), Godoi (2010), Sabaini (2012), Sinhoretto (2013), entre outros.

2. O sequestro do empresário Abílio Diniz foi bastante comentado na mídia na época. Alguns estudos realizados apontaram para o impacto causado nas eleições presidenciais depois do ocorrido. Para maiores informações, ver: http://www.redebrasilatual.com.br/blog/blog-na-rede/ em-1989-sequestro-de-abilio-diniz-foi-relacionado-ao-pt-e-desmentido-logo-apos-eleicoesmostra-pesquisa. Acesso em: 30/01/2012.

3. Analiso mais profundamente a relação entre as regras institucionais e a atuação dos agentes prisionais em minha dissertação de mestrado. Ver Taets (2012); ver também Marques (2009).

4. Em minha dissertação de mestrado analiso mais profundamente a aprendizagem da profissão de agente prisional em relação às ordens internas que regem o cotidiano do presídio e sua manipulação por parte tanto das agentes prisionais quanto das presas. Ver Taets (2012).

5. A questão da identidade da agente prisional em oposição à identidade das presas está bastante presente na fala de diversas guardas com quem trabalhei durante a pesquisa, já que a proximidade tanto física quanto social entre elas é enorme. Para mais detalhes, ver Taets (2012).

6. Castro e Silva (2008), a partir de pesquisa realizada em presídios fluminenses, aponta o quanto as regras prisionais são negociadas constantemente dentro do cárcere, não sendo, pois, estabelecidas de antemão na letra da lei, mas antes no convívio prisional entre agentes e detentos.

7. Suzane Von Richthofen foi condenada a 39 anos e meio de prisão pela morte de seus pais, o casal Manfred e Marísia Von Richthofen. Suzane confessou a participação no crime e foi presa, juntamente com o namorado e o irmão deste, Daniel e Christian Cravinhos. Folha.com, Cotidiano, 22/07/2006. Acesso em: 29/12/2011.

8. Também em minha dissertação de mestrado discuto o quanto as origens sociais de presas e agentes prisionais são parecidas, sendo compartilhados por elas, muitas vezes, os mesmos bairros de origem, o nível educacional etc. Ver Taets (2012).

9. "Sistema" é a forma como a maioria das guardas nomeia o Sistema Prisional.

10. Penitenciária Feminina da Capital, presídio feminino na cidade de São Paulo, SP.

11. Tatuapé é um bairro na zona leste da cidade de São Paulo, enquanto Santana encontra-se na zona norte.

12. Na fala de diversas outras guardas entrevistadas para a pesquisa realizada, foi possível perceber que muitas delas identificavam um processo de adoecimento devido à dificuldade de separar as experiências vividas dentro do cárcere e aquelas vivenciadas fora dele. Ver Taets (2012).

13. Salla (2006), ao traçar o histórico das rebeliões prisionais no estado de São Paulo a partir dos anos 1990, afirma que os coletivos de presos passaram a atuar de forma mais organizada dentro dos presídios desde o momento em que o Estado abriu mão do controle da dinâmica prisional. Estudos mais recentes, no entanto, apontam para a maneira como a presença deste coletivo vem organizando a dinâmica prisional e também das periferias de São Paulo. Tais estudos indicam um compartilhamento das responsabilidades entre Estado e coletivo de presos, sempre numa relação 
tensa. Ver Sinhoretto, Silvertre e Melo (2013); Feltran (2010); Biondi e Marques (2010), entre outros.

14. Biondi e Marques (2010), ao pesquisarem diferentes "comandos" de presos - PCC e CRBC encontraram-se diante de uma disputa discursiva em que historicidades diversas eram acionadas para legitimar os grupos em confronto. Presos ligados ao PCC afirmam que a atuação deste grupo humanizou os presídios, ou organizou o espaço prisional de forma a evitar a opressão entre os presos e as mortes dentro do espaço prisional. Presos ligados a outros grupos, no entanto, atestam que o PCC, na verdade, oprime a população prisional ao proteger apenas aqueles que estão formalmente ligados a este comando.

15. Ser "batizada no partido" significa fazer parte da organização, atuando em seu favor.

\section{RESUMOS}

Este artigo debruça-se sobre narrativas do cárcere. A partir da análise das narrativas sobre a trajetória profissional de uma agente prisional em particular, é possível pensar em diversos aspectos que envolvem a experiência dentro do cárcere, dentre eles, a dor, a memória e a violência. Desde os conceitos trabalhados por Halbwachs sobre memória e Veena Das acerca da experiência violenta e o trabalho do tempo, o artigo pretende abordar a elaboração de narrativas de situações em que a dor e a violência não apenas se mostram presentes, mas principalmente organizam a estrutura narrativa. Tendo como base uma pesquisa etnográfica realizada com agentes prisionais femininas no estado de São Paulo, o artigo discute a maneira como a experiência no cárcere pode ser compreendida através das histórias construídas no intuito de compartilhar a dor vivenciada ali dentro.

This article aims to discuss prison's narratives. Through the analyses of a prison safety guardian trajectory, it is possible to think about a lot of issues, as we can see: experience inside prison, pain, memory and violence. Since the concepts of Halbwachs about memory and Veena Das about the violent experience and the role of the time, this article aims to privilege the narrative's construction on specially situations when the pain and the violence are not just present, but, besides that, they structure the narrative. Based on the ethnographic data, from a research realized with some prison safety female guardians in São Paulo, this article discuss how the prison experience can be comprehend trough the narratives built to share the pain that people suffered inside there.

\section{ÍNDICE}

Keywords: Prison, narrative, violence, pain, experience, prison safety guardians.

Palavras-chave: Cárcere, narrativa, violência, dor, experiência, agentes de segurança penitenciária. 


\section{AUTOR}

\section{ADRIANA REZENDE FARIA TAETS}

USP. Adriana Rezende Faria Taets é mestre em Antropologia Social pela Universidade de São Paulo e doutoranda em Antropologia Social pela mesma instituição. Atua como professora em instituições de ensino privado, tanto no nível superior quanto no ensino médio. Contato: dritaets@yahoo.com.br 